\title{
Comparative study of the synovial histology in rheumatoid arthritis, spondyloarthropathy, and osteoarthritis: influence of disease duration and activity
}

D Baeten, P Demetter, C Cuvelier, F Van den Bosch, E Kruithof, N Van Damme, $G$ Verbruggen, $H$ Mielants, E M Veys, F De Keyser

\begin{abstract}
Objectives-To compare the macroscopic and microscopic characteristics of synovial tissue in rheumatoid arthritis (RA), spondyloarthropathy (SpA), and osteoarthritis (OA) after exclusion of possible biases induced by disease duration or activity, or both.

Methods-Synovial biopsy specimens were obtained by needle arthroscopy in patients with early RA $(n=16)$, late $R A$ $(n=14)$, early SpA $(n=23)$, and OA $(n=12)$. Macroscopic and microscopic features were scored on a four point scale and analysed as a function of disease duration (early versus late RA), local and systemic disease activity, and diagnosis.
\end{abstract}

Results-Except for the maximal synovial lining thickness, no significant differences were seen between early and late RA. For disease activity, synovial histology was only weakly correlated with $\mathrm{C}$ reactive protein in RA, but seemed to be strongly dependent on effusion of the biopsied joint in all disease groups. After stratification for local disease activity, no disease related differences were found in patients without joint effusion. In contrast, important differences were found between patients with RA and $\mathrm{SpA}$ with active joint effusion. Synovial vascularity was macroscopically increased in SpA versus RA $(p=0.017)$. A straight vessel pattern was only seen in RA, while tortuous vessels were preferentially seen in SpA. Vascularity was also microscopically increased in SpA compared with $R A(p=0.031)$, and correlated with the macroscopic vascularity $\left(r_{s}=0.36, p=0.036\right)$. CD3 $+(p=0.008)$, $\mathrm{CD} 4+(p=0.008)$, and CD20+ $(p=0.024)$ lymphocytes were overrepresented in RA compared with SpA. The integrin expression in RA was characterised by a decrease of $\alpha \mathrm{V} \beta 3$ in the synovial lining $(p=0.006)$ and an increase of $\alpha \mathrm{V} \beta 5$ in the sublining $(\mathrm{p}<0.001)$.

Conclusions-The immune architecture of the synovial membrane is more dependent on local disease activity than on disease duration. Synovium obtained from clinically affected joints shows important histological differences between RA and SpA.

(Ann Rheum Dis 2000;59:945-953)
Synovitis is a major characteristic of chronic inflammatory joint diseases of autoimmune origin, such as rheumatoid arthritis (RA) and spondyloarthropathy (SpA). It can also occur as a secondary inflammatory symptom in osteoarthritis (OA), which is primarily induced by biomechanical stress on cartilage and subchondral bone. Studies in RA indicate that the synovial membrane has a dominant role in the joint inflammation and destruction, as suggested by the changes in synovial histology: (a) thickening of the synovial lining layer, as a result of infiltration by CD68+ cells ${ }^{1}$ and both proliferation and reduced apoptosis of type $\mathrm{B}$ synoviocytes $^{2-5}$; (b) neovascularisation of the sublining layer ${ }^{6-8} ;(c)$ infiltration of the sublining with $\mathrm{T}$ and $\mathrm{B}$ lymphocytes, ${ }^{9-12}$ plasma cells, ${ }^{10}{ }^{12}$ and macrophages ${ }^{12}$; and $(d)$ alteration of the adhesion molecule expression, including the expression of $\alpha \mathrm{V}$ integrins which may have a role in both neovascularisation and pannus formation. ${ }^{1314}$

These observations suggest that the synovial membrane is both the primary site of inflammation, triggered by autoreactive $\mathrm{T}$ cells and macrophages, and the main effector organ, as the hyperplastic "aggressive" pannus leads to cartilage and bone erosion. ${ }^{15-17}$ However, most of these histological studies have used synovial tissue obtained at the time of surgery, thereby creating a selection bias of the patient group for disease duration and activity. ${ }^{18}{ }^{19}$ It remains, therefore, unclear if the observed histological changes are of primary pathogenic relevance, or if they are secondary bystander phenomena of the chronic joint inflammation and destruction. Moreover, the use of surgery specimens also biased the choice of the control group towards OA, and most studies failed to include other inflammatory arthritides, such as SpA. Thus both the specificity of the observations in RA and the histology of the synovial membrane in $\mathrm{SpA}$ remain largely to be investigated.

Owing to the development of needle arthroscopy, which made it possible to visualise and sample the synovial membrane in early and late stages of all types of peripheral joint diseases, ${ }^{20}$ this study aims at describing disease related histological features of the synovial membrane. Firstly, it investigates the influence of disease duration (early versus late RA) and activity (presence of joint effusion, sedimentation rate, $\mathrm{C}$ reactive protein (CRP), swollen joint count) on synovial histology. Secondly, after correction for these possible biases by appropriate 
stratification it compares systematically the synovial lining hypertrophia, the vascularity, the cellular infiltration, and the $\alpha \mathrm{V}$ integrin expression in RA, SpA, and OA.

\section{Materials and methods}

PATIENTS

Synovial tissue samples were obtained from 71 consecutive patients undergoing needle arthroscopy of the knee for pain or synovitis, or both. Thirty patients were diagnosed as RA, according to the American College of Rheumatology (ACR) criteria. ${ }^{21}$ Of these patients with RA, 16 had early disease, defined as a disease duration of less than one year as measured from the first symptoms of arthritis, and $14 \mathrm{had}$ a longstanding disease ( $>1$ year, range 1.5-20). Twenty three patients were diagnosed as SpA, according to the European Spondyloarthropathy Study Group criteria ${ }^{22}$ : five patients with ankylosing spondylitis, 10 with psoriatic arthritis, and eight undifferentiated spondyloarthropathies. All patients with SpA had a disease duration of less than one year. OA was diagnosed in 12 patients, according to the ACR criteria. $^{23}$ The remaining six patients were excluded from the study as no definite diagnosis could be made. Age, sex, disease duration, and use of drugs were recorded. The total number of swollen joints (including hands, wrists, elbows, shoulders, knees, ankles, and feet) and the presence of joint effusion in the investigated knee were evaluated clinically: effusion in the investigated knee was considered to be a primary variable for local disease activity as other symptoms of synovial inflammation (warmth, swelling,...) were virtually always associated with the presence of synovial fluid. Laboratory investigations included the measurement of serum CRP, erythrocyte sedimentation rate, and rheumatoid factor, and HLA typing. Joint destruction was assessed by $x$ ray, using the Steinbrocker criteria. ${ }^{24}$ Table 1 summarises the features of the different patient groups.

Synovial biopsy specimens were obtained by needle arthroscopy as described previously. ${ }^{20}$ Briefly, needle arthroscopy of the knee was performed under local anaesthesia using a 2.7 mm Hopkins rod-lens telescope (Karl Storz, Tuttlingen, Germany). The joint cavity was carefully inspected, and synovial vascularity and hypertrophia were scored on a four point semiquantitative scale by an experienced arthroscopist (DB or FVdB). ${ }^{20}$ The morphology of the blood vessels was described as a straight, tortuous, or mixed pattern. ${ }^{25}$ Synovial membrane biopsy specimens $(n=10)$ were obtained from the macroscopically inflamed areas with a $2.7 \mathrm{~mm}$ biopsy forceps (Karl Storz). In each patient, five biopsy specimens were stored in formaldehyde and embedded in paraffin. Sections, $5 \mu \mathrm{m}$, were cut and stained with haematoxylin-eosin for histological analysis. The remaining five biopsy specimens were snap frozen and mounted in Jung tissue freezing medium (Leica Instruments, Nussloch, Germany). Frozen sections were cut and mounted on Star Frost glass slides (Knittelgläser, Braunschweig, Germany). Both paraffin embedded and frozen sections were used for immunohistochemistry.

\section{IMMUNOHISTOCHEMISTRY}

Paraffin embedded sections were dewaxed, heated in a microwave oven in citrate buffer (0.1 mol/1, $\mathrm{pH}$ 6.0) for antigen retrieval, and incubated for 60 minutes with the following mouse monoclonal antibodies (mAbs): antiCD20 (clone L26, Dako, Glostrup, Denmark), anti-plasma cell (clone VS38c, Dako), antiCD68 (clone PG-M1, Dako). Frozen sections were fixed for 10 minutes in acetone and incubated for 30 minutes with the following mouse mAbs: anti-CD3 (clone UCHT1, Dako), antiCD4 (clone MT310, Dako), anti-CD8 (clone DK25, Dako), anti- $\alpha \mathrm{V} \beta 3$ (clone 23C6, Pharmingen, San Diego, USA), and anti- $\alpha$ V $\beta 5$ (clone P1F6, Chemicon International Inc, Temecula, USA). Parallel sections were incubated with irrelevant isotype matched $\mathrm{mAb}$ as negative control. After rinsing, the endogenous peroxidase was blocked with $1 \%$ hydrogen peroxide. The sections were subsequently incubated for 15 minutes with a biotinylated antimouse secondary antibody, followed by 15 minutes with a streptavidin-peroxidase complex (LSAB+ Kit, Dako). The colour reaction was developed with 3-amino-9-ethylcarbazole substrate (Dako) as chromogen. Finally, the sections were counterstained with haematoxylin. All incubations were carried out at room temperature and the sections were washed with phosphate buffered saline between all steps.

Table 1 Clinical data of the patients with early rheumatoid arthritis (early $R A$; disease duration of less than one year), late rheumatoid arthritis (late $R A$; disease duration of more than one year), spondyloarthropathy ( $\mathrm{S} p A)$, and osteoarthritis $(O A)$. Mean (standard deviation) (range)

\begin{tabular}{lllll}
\hline & Early RA & Late $R A$ & SpA & OA \\
\hline Number of patients & 16 & 14 & 23 & 12 \\
Sex (M/F) & $6 / 10$ & $3 / 11$ & $13 / 10$ & $5 / 7$ \\
Age (years) & $51(17)(18-80)$ & $56(12)(36-81)$ & $41(15)(19-64)$ & $62(15)(38-80)$ \\
Disease duration (years) & $0.6(0.3)(0.2-1)$ & $8.5(5.7)(1.5-20)$ & $0.7(0.5)(0.1-1)$ & Unknown \\
Joint effusion of the knee (+/-) & $10 / 6$ & $8 / 6$ & $13 / 10$ & $3 / 9$ \\
Number of swollen joints & $6.9(4.7)$ & $6.8(6.6)$ & $1.6(0.8)$ & $1.2(0.9)$ \\
Serum CRP (mg/l) & $36(26)$ & $42(41)$ & $24(23)$ & $05(03)$ \\
Sedimentation rate (mm/1st h) & $35(25)$ & $38(18)$ & $24(18)$ & $13(9)$ \\
Shared epitope (+/-) & $12 / 4$ & $11 / 3$ & $6 / 17$ & $3 / 9$ \\
HLA-B27 (+/-) & $0 / 16$ & $1 / 13$ & $11 / 12$ & $0 / 12$ \\
Rheumatoid factor (+/-) & $6 / 10$ & $10 / 4$ & $0 / 23$ & 0.12 \\
$x$ Ray score & $0.80(0.86)$ & $1.17(1.11)$ & $0.23(0.69)$ & $4 / 8$ \\
NSAID ${ }^{\star}(+/-)$ & $13 / 3$ & $6 / 8$ & $12 / 11$ & $0 / 12$ \\
DMARD $(+/-)$ & $1 / 15$ & $6 / 8$ & $8 / 15$ & $0 / 12$ \\
Corticosteroids (+/-) & $5 / 11$ & $6 / 8$ & $2 / 21$ & $1.07)$ \\
\hline
\end{tabular}

${ }^{\star} \mathrm{CRP}=\mathrm{C}$ reactive protein NSAID $=$ non-steroidal anti-inflammatory drug; DMARD $=$ disease modifying antirheumatic drug. 
MICROSCOPIC ANALYSIS

Stained sections were coded and analysed by two independent observers who were unaware of the diagnosis and clinical data. The analysis included all areas of the five biopsy specimens and a global score was given for each variable. A semiquantitative four point scale was developed according to previously used scoring systems for synovial tissue ${ }^{101226-28}$ : zero represented the lowest and three the highest level of expression. As some histological markers are more abundant than others in synovial tissue, the scoring system was calibrated for each marker separately by examining a representative number of synovial samples. Thus the sensitivity of the scoring system was different for each marker, allowing comparison of a specific marker between the different patient groups, but not comparison of different markers in one group. This semiquantitative scale was used for all variables, unless indicated otherwise. The synovial lining layer was scored for the number of CD68+ cells, the mean lining layer thickness, and the maximal lining layer thickness. Mean and maximal lining thickness were scored separately as it appeared that synovial lining layer hyperplasia can be focal and thus that both variables can be discrepant in some samples. The mean thickness of the synovial lining layer was evaluated by counting the number of cell layers in six randomly selected regions and calculating the mean. ${ }^{29}$ The maximal thickness was scored semiquantitatively $(0: 1-2 ; 1: 3-4 ; 2: 5-6 ; 3: \geqslant 7$ cell layers $) .{ }^{102}$ In the sublining the vascularity was evaluated by the number of blood vessels and their localisation (superficial, profound, diffuse). Infiltration of the sublining layer with inflammatory cells was evaluated by the global number of infiltrating cells, the number of lymphocytes, plasma cells, and neutrophils, and the presence of lymphoid aggregates $(+/-)$. Additionally, immunohistochemical stainings were scored for CD68, CD20, CD3, CD4, CD8, and plasma cells. Finally, the expression of the integrins $\alpha \mathrm{V} \beta 3$ and $\alpha \mathrm{V} \beta 5$ was scored in three compartments: synovial lining layer, sublining layer, and endothelium. The scores obtained by the two observers were concordant in more than 95\% of cases. When discordant scores were obtained, which differed by a maximum of one point, the mean of the two scores was used.

\section{STRATIFICATION}

The following factors that might influence the comparison of RA, SpA, and OA samples were analysed in the first part of the study: disease duration, presence of effusion in the biopsied joint, CRP, sedimentation rate, and swollen joint count. Factors that seemed significantly to influence the histological features were subsequently used for stratification of the second part of the study in order to avoid systematic biases in the comparison of RA, SpA, and OA.

\section{STATISTICAL ANALYSIS}

To avoid statistical biases created by multiple comparisons, the Kruskal-Wallis test was used for comparing the mean scores in the different patient groups; only when this test showed significant differences, were the exact $\mathrm{p}$ values calculated with the Mann-Whitney U test and corrected for the number of comparisons. Spearman's test was used for correlations. $\mathrm{p}<0.05$ was considered to be significant.

\section{Results}

INFLUENCE OF DISEASE DURATION ON SYNOVIAL HISTOLOGY IN RA

To determine whether the macroscopic and microscopic features of the synovial membrane were dependent on disease duration, the 16 patients with early RA were compared with the 14 patients with late RA. No significant differences in macroscopic vascularity or villous hypertrophia were seen. At the microscopic level the only difference was an increased maximal lining thickness in late RA (mean (SEM) $2.50(0.19)$ ) compared with early RA (1.73 (0.20), $p=0.013)$, whereas the mean lining thickness was not increased in late $(2.26$ (0.34)) $v$ early RA (2.30 (0.33)). As no other significant differences were seen, either in vas-

Table 2 Microscopic features of the synovial membrane in rheumatoid arthritis (RA) with or without joint effusion, spondyloarthropathy $(S p A)$ with or without joint effusion, and osteoarthritis (OA) with or without joint effusion. Mean histological score (standard error of the mean)

\begin{tabular}{|c|c|c|c|c|c|c|}
\hline & $\begin{array}{l}R A \text { with joint } \\
\text { effusion }(n=18)\end{array}$ & $\begin{array}{l}R A \text { without } \\
\text { joint effusion } \\
(n=12)\end{array}$ & $\begin{array}{l}\text { SpA with joint } \\
\text { effusion }(n=13)\end{array}$ & $\begin{array}{l}\text { SpA without } \\
\text { joint effusion } \\
(n=10)\end{array}$ & $\begin{array}{l}O A \text { with joint } \\
\text { effusion }(n=3)\end{array}$ & $\begin{array}{l}\text { OA without } \\
\text { joint effusion } \\
(n=9)\end{array}$ \\
\hline Mean lining thickness & $2.69(0.30)^{\star}$ & $1.68(0.31)^{\star}$ & $3.48(0.66)$ & $2.02(0.35)$ & $2.47(0.79)$ & $1.40(0.18)$ \\
\hline Max lining thickness & $2.31(0.18)$ & $1.71(0.29)$ & $1.36(0.20)$ & $1.33(0.33)$ & $1.67(0.33)$ & $1.25(0.25)$ \\
\hline CD68 in lining & $1.06(0.24)$ & $0.77(0.26)$ & $1.69(0.24)^{\star}$ & $0.81(0.27)^{\star}$ & $1.33(0.67)$ & $0.89(0.26)$ \\
\hline$\alpha \mathrm{V} \beta 3$ in lining & $1.09(0.31) \dagger$ & $1.20(0.58)$ & $2.40(0.16) \dagger$ & $2.25(0.25)$ & $1.33(0.33)$ & $1.00(0.41)$ \\
\hline$\alpha \mathrm{V} \beta 5$ in lining & $2.73(0.14)$ & $2.50(0.50)$ & $2.55(0.16)$ & $1.80(0.49)$ & $2.67(0.33)$ & $1.5(0.87)$ \\
\hline Vascularity & $1.58(0.14)^{\star} \dagger$ & $1.04(0.18)^{\star}$ & $2.23(0.29) \dagger$ & $1.60(0.27)$ & $2.00(0.00)$ & $0.78(0.22)$ \\
\hline Infiltration & $1.92(0.15)^{\star}$ & $0.59(0.18)^{\star}$ & $2.08(0.25)^{\star}$ & $0.80(0.20)^{\star}$ & $1.50(0.29)$ & $0.22(0.15)$ \\
\hline Neutrophils & $0.66(0.17)$ & $0.27(0.20)$ & $1.31(0.35)$ & $0.45(0.24)$ & $0.67(0.33)$ & $0.11(0.11)$ \\
\hline Lymphocytes & $1.92(0.09)^{\star}$ & $0.86(0.23)^{\star}$ & $1.88(0.26)^{\star}$ & $0.95(0.26)^{\star}$ & $1.67(0.33)$ & $0.22(0.15)$ \\
\hline Plasma cells & $0.90(0.23)^{\star}$ & $0.09(0.09)^{\star}$ & $0.38(0.15)$ & $0.00(0.00)$ & $0.00(0.00)$ & $0.11(0.11)$ \\
\hline CD68 in sublining & $1.34(0.28)$ & $0.68(0.27)$ & $1.23(0.20)^{\star}$ & $0.28(0.15)^{\star}$ & $0.67(0.33)$ & $0.33(0.24)$ \\
\hline CD38 & $0.44(0.19)$ & $0.17(0.17)$ & $0.56(0.31)$ & $0.14(0.14)$ & $1.07(0.73)$ & $0.33(0.33)$ \\
\hline $\mathrm{CD} 20$ & $0.94(0.27) \dagger$ & $0.14(0.10)$ & $0.15(0.15)^{\star} \dagger$ & $0.22(0.15)^{\star}$ & $0.00(0.00)$ & $0.11(0.11)$ \\
\hline CD3 & $2.41(0.16)^{\star} \dagger$ & $0.64(0.24)^{\star}$ & $1.55(0.27)^{\star} \dagger$ & $0.58(0.27)^{\star}$ & $1.00(0.00)$ & $0.72(0.28)$ \\
\hline $\mathrm{CD} 4$ & $1.91(0.19)^{\star} \dagger$ & $0.32(0.19)^{\star}$ & $0.95(0.24) \dagger$ & $0.25(0.17)$ & $1.00(0.58)$ & $0.44(0.18)$ \\
\hline CD8 & $1.62(0.20)^{\star}$ & $0.45(0.16)^{\star}$ & $1.40(0.28)^{\star}$ & $0.08(0.08)^{\star}$ & $1.00(0.58)$ & $0.44(0.18)$ \\
\hline$\alpha \mathrm{V} \beta 5$ in sublining & $2.45(0.21)^{\star} \dagger$ & $0.50(0.50)^{\star}$ & $0.55(0.25) \dagger$ & $0.00(0.00)$ & $0.33(0.00)$ & $0.00(0.00)$ \\
\hline$\alpha \mathrm{V} \beta 3$ on endothelium & $1.64(0.34)$ & $0.4(0.4)$ & $1.20(0.33)$ & $1.00(0.71)$ & $0.00(0.00)$ & $0.00(0.00)$ \\
\hline$\alpha \mathrm{V} \beta 5$ on endothelium & $0.46(0.25)$ & $0.0(0.0)$ & $0.09(0.09)$ & $0.00(0.00)$ & $0.00(0.00)$ & $0.00(0.00)$ \\
\hline
\end{tabular}

${ }^{\star} \mathrm{p}<0.05$ for comparison of patients with and without joint effusion within one diagnostic group. $t \mathrm{p}<0.05$ for comparison of patients with RA with joint effusion and patients with SpA with joint effusion. 
cularity, inflammatory infiltration, or $\alpha \mathrm{V}$ integrin expression, the patients with early and late RA were considered as one group for further analysis.

INFLUENCE OF LOCAL DISEASE ACTIVITY ON SYNOVIAL HISTOLOGY

As synovial membrane samples were obtained both from patients with active joint effusion and patients with only knee pain, which might be due to secondary cartilage damage rather than to synovial inflammation, the influence of local disease activity on synovial histology was analysed by comparing patients with and without effusion of the biopsied joint. Table 2 summarises these results. In RA, most histological variables were increased in the 18 patients with joint effusion compared with the 12 patients without joint effusion, reaching significance for mean lining thickness $(p=0.040)$, vascularity $(\mathrm{p}=0.023)$, and inflammatory infiltration $(\mathrm{p}<0.001)$, number of lymphocytes $(\mathrm{p}<0.001)$, plasma cells $(\mathrm{p}=0.013), \mathrm{CD} 3+$ cells $(p<0.001)$, CD $4+$ cells $(p<0.001)$, and CD8+ cells $(p=0.001)$, and expression of $\alpha \mathrm{V} \beta 5$ in the sublining layer $(p=0.027$ ) (fig $1 \mathrm{~A})$. Lymphoid
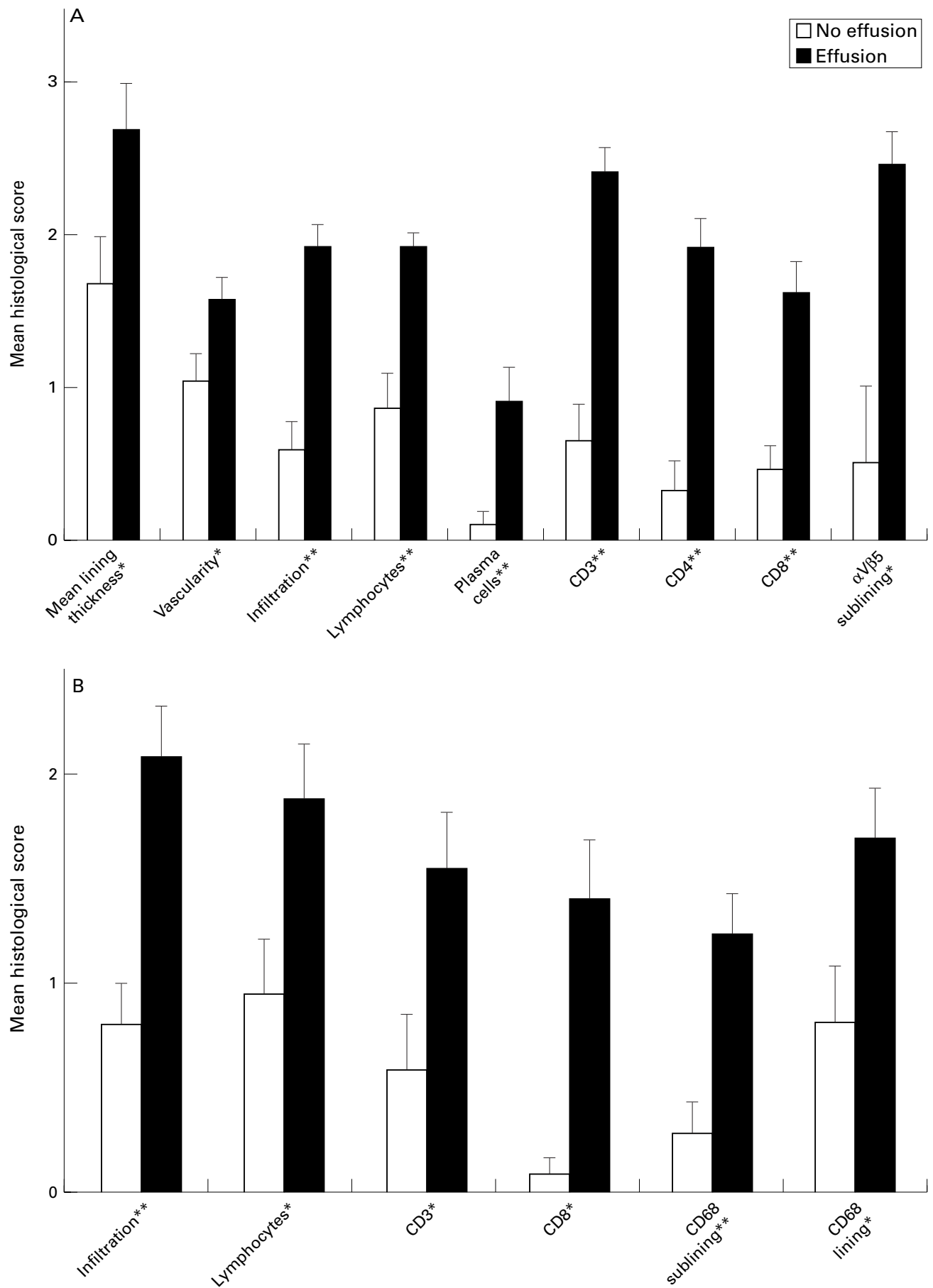

Figure 1 Comparison of the histological scores in patients with and without effusion of the biopsied joint. Mean (standard error of the mean). ${ }^{*} p<0.05 .{ }^{\star} p<0.01$. (A) Patients with rheumatoid arthritis with $(n=18)$ and without joint effusion $(n=12)$. (B) Patients with spondyloarthropathy with $(n=13)$ and without joint effusion $(n=10)$. 
Table 3. Macroscopic morphology of the synovial blood vessels in rheumatoid arthritis $(R A)$ and spondyloarthropathy (SpA): straight vessels, tortuous vessels, or mixed pattern. Results are shown as number (\%)

\begin{tabular}{lll}
\hline & $R A(n=18)$ & $S p A(n=13)$ \\
\hline Straight & $5(28)$ & $0(0)$ \\
Tortuous & $5(28)$ & $8(62)$ \\
Mixed & $8(44)$ & $5(38)$ \\
\hline
\end{tabular}

aggregates were seen in eight patients with RA with joint effusion (44\%), but in none of the patients without effusion. A similar trend was found in the $\mathrm{SpA}$ group, with an increase in degree of infiltration $(p=0.003)$, number of lymphocytes $\quad(\mathrm{p}=0.030), \quad \mathrm{CD} 3+\quad$ cells $(\mathrm{p}=0.031), \mathrm{CD} 8+$ cells $(\mathrm{p}=0.011), \mathrm{CD} 68+$ cells in the lining layer $(p=0.025)$, and CD68+ cells in the sublining layer $(\mathrm{p}=0.006)$ (fig $1 \mathrm{~B})$. Also in OA strong vascularity and infiltration was only found in patients with joint effusion, but these differences did not reach significance owing to the small number of observations (only three patients with joint effusion). Because of the significant impact of local disease activity on the synovial histology in all patient groups, further comparisons were stratified for the presence or absence of effusion in the biopsied joint.

INFLUENCE OF SYSTEMIC DISEASE ACTIVITY ON SYNOVIAL HISTOLOGY

Systemic disease activity, as evaluated by CRP serum concentrations, sedimentation rate, and number of swollen joints, had less influence on the histological findings. In RA, the CRP level correlated with the degree of inflammatory infiltration $\left(r_{s}=0.46, \mathrm{p}=0.013\right)$, the number of lymphocytes $\left(r_{s}=0.41, \mathrm{p}=0.027\right), \mathrm{CD} 3+$ cells $\left(r_{s}=0.44, \mathrm{p}=0.021\right), \mathrm{CD} 4+$ cells $\quad\left(r_{s}=0.58\right.$,

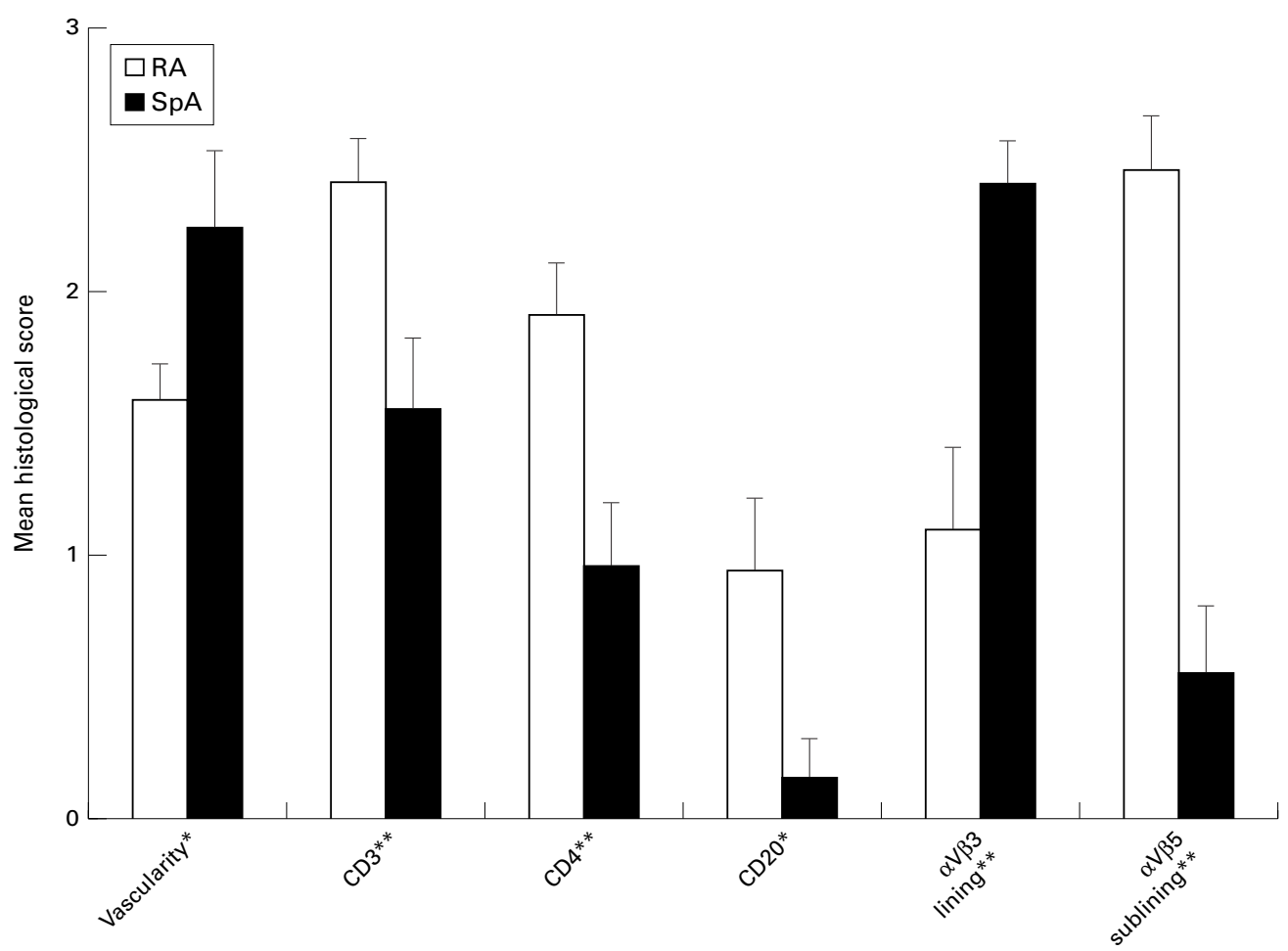

Figure 2 Comparison of the histological scores in 18 patients with rheumatoid arthritis $(R A)$ and 13 patients with spondyloarthropathy $(S p A)$ with effusion of the biopsied joint. Mean (standard error of the mean). ${ }^{\star} p<0.05$. ${ }^{\star \star} p<0.01$.

$\mathrm{p}=0.002), \mathrm{CD} 8+$ cells $\left(r_{s}=0.54, \mathrm{p}=0.003\right)$, CD68+ cells in the sublining layer $\left(r_{s}=0.52\right.$, $\mathrm{p}=0.007), \alpha \mathrm{V} \beta 3$ expression on endothelium $(r=0.77, \mathrm{p}=0.001)$, and $\alpha \mathrm{V} \beta 5$ expression in the sublining layer $\left(r_{s}=0.71, \mathrm{p}=0.006\right)$. Similar correlations were found with the sedimentation rate, but not with the number of swollen joints. However, in SpA and OA there were no significant correlations between systemic variables of disease activity and histological findings. Moreover, when this analysis was corrected for the influence of local disease activity, by including only patients with active effusion of the biopsied joint, the only significant observations were the correlation in patients with RA of CRP with the number of CD4+ cells $\left(r_{s}=0.54, \mathrm{p}=0.031\right), \mathrm{CD} 8+$ cells $\quad\left(r_{s}=0.50\right.$, $\mathrm{p}=0.049)$, and $\alpha \mathrm{V} \beta 3$ expression on endothelium $\left(r_{s}=0.64, \mathrm{p}=0.033\right)$.

MACROSCOPIC AND MICROSCOPIC FEATURES OF THE SYNOVIAL MEMBRANE IN RA VERSUS SPA, WITHOUT EFFUSION OF THE BIOPSIED JOINT

When the patients without active joint effusion were analysed, no differences were noted in macroscopic or microscopic features of the synovial membrane between RA ( $n=12), S p A$ $(\mathrm{n}=10)$, and OA $(\mathrm{n}=9)($ table 2$)$.

MACROSCOPIC FEATURES OF THE SYNOVIAL MEMBRANE IN PATIENTS WITH RA VERSUS PATIENTS WITH SPA WITH EFFUSION OF THE BIOPSIED JOINT

OA was not included in this analysis owing to the small sample number of patients with active joint effusion $(n=3)$. Patients with RA $(n=18)$ and $\operatorname{SpA}(n=13)$ with clinical joint effusion showed a similar degree of villous hypertrophia $(1.31(0.26) v 1.38(0.29))$, but the macro- 
scopic vascular pattern was clearly different. The vascularity was significantly increased in SpA (2.08 (0.28)) compared with RA (1.22 (0.19), $\mathrm{p}=0.017)$. Moreover, the morphology of the blood vessels was different: straight vessels were preferentially seen in RA, whereas tortuous vessels were predominant in SpA. However, a manifest tortuous pattern was also seen in $5 / 18(28 \%)$ of the patients with RA, and a mixed pattern was common in both groups (table 3).

MICROSCOPIC FEATURES OF THE SYNOVIAL MEMBRANE IN PATIENTS WITH RA VERSUS PATIENTS WITH SPA WITH EFFUSION OF THE BIOPSIED JOINT

Table 2 shows the histological and immunohistochemical data and fig 2 illustrates the main differences between RA and SpA. No differences were observed in the synovial lining layer: mean lining thickness, maximal lining thickness, and number of CD68+ cells were similar in both groups. In the sublining layer, vascularity was increased in $\mathrm{SpA}(2.23(0.29))$ compared with RA (1.58 (0.14), p=0.031), thus confirming the macroscopic observations. Microscopic and macroscopic vascularity correlated weakly $\left(r_{s}=0.36, p=0.036\right)$. Both in RA and $\mathrm{SpA}$, the blood vessels were preferentially seen in the superficial layers just beneath the synovial lining layer. The overall degree of inflammatory infiltration of the sublining layer was similar in RA and SpA. There were no significant differences in number of macrophages (CD68+), plasma cells, and neutrophils. However, RA synovium showed an important lymphocytic infiltration with an increase in number of CD3+ cells (2.41 (0.16) $v 1.55$ (0.27), $\mathrm{p}=0.008), \mathrm{CD} 4+$ cells $(1.91(0.19) v$ $0.95(0.24), \mathrm{p}=0.008)$, and CD20+ cells $(0.94$ (0.27) $v 0.15$ (0.15), $\mathrm{p}=0.024)$. The number of CD8+ cells was not increased. Lymphoid aggregates were seen in 8/18 patients with RA, but in only $2 / 13$ patients with SpA. Finally, the integrins $\alpha \mathrm{V} \beta 3$ and $\alpha \mathrm{V} \beta 5$ were differentially
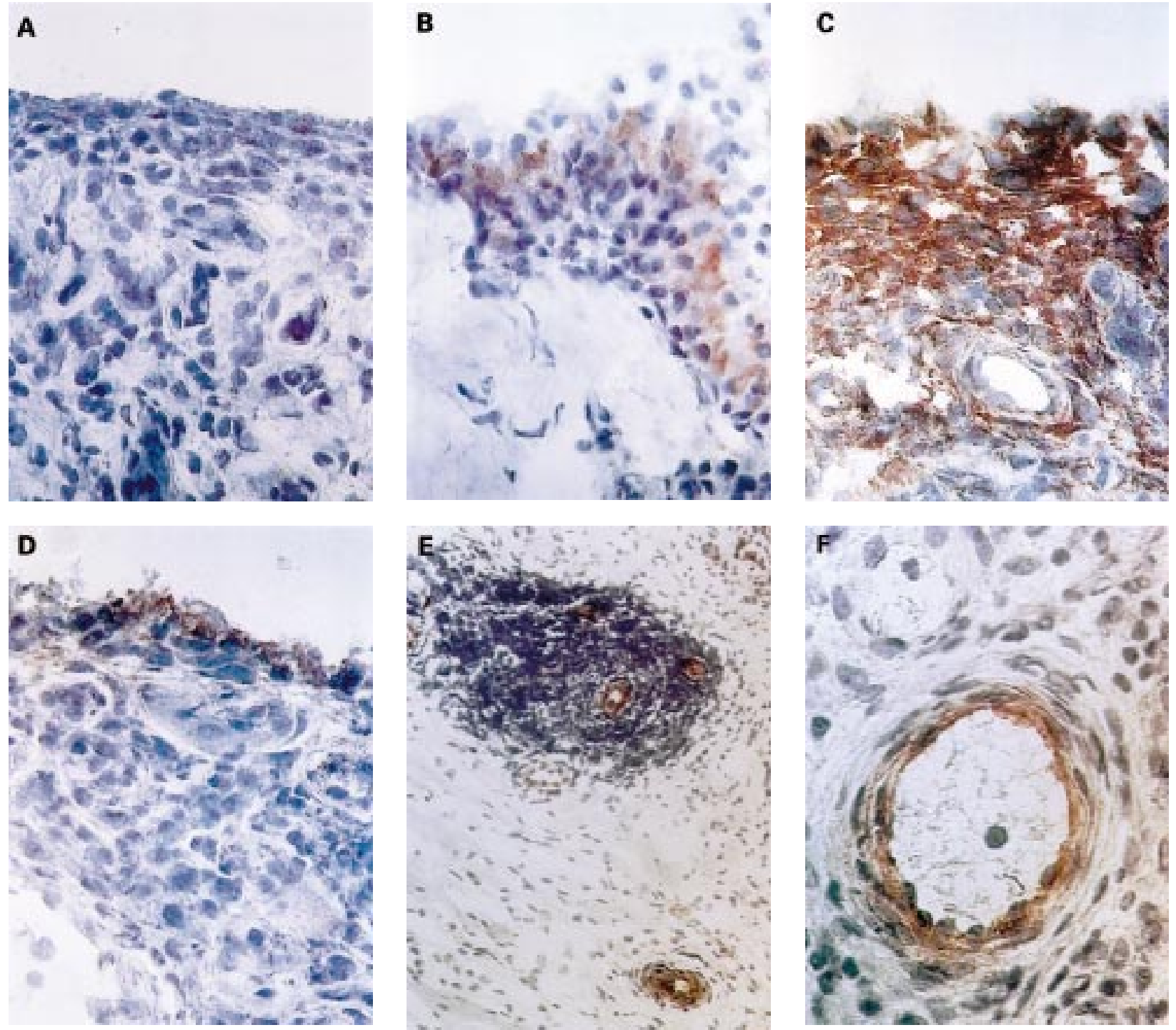

Figure $3 a V$ integrin expression in the synovial membrane. Frozen sections of synovial biopsy specimens from $R A(A$ and $C)$ and $S p A(B$ and $D)$ were stained immunohistochemically for $\alpha V \beta 3$ ( $A$ and $B)$ and $\alpha V \beta 5(C$ and $D)$. (A) aVR3 expression in $R A$ synovium: no staining of synovial lining cells. (B) aVB3 expression in SpA synovium: staining of synovial lining cells. (C) aV $\beta 5$ expression in $R A$ synovium: staining of superficial synovial lining cells and of sublining cells. (D) aVB5 expression in SpA synovium: staining of superficial synovial lining cells, but not of sublining cells. (E) aVB3 expression on endothelial cells in $R A$ synovium. (F) aVB3 expression on endothelial cells in SpA synovium. 
expressed in both patient groups (fig 3). In the synovial lining layer, the expression of $\alpha \mathrm{V} \beta 3$ was decreased in RA $(1.09(0.31)) v \operatorname{SpA}(2.40$ $(0.16), p=0.006)$. In the sublining layer, the expression of $\alpha \mathrm{V} \beta 5$ was increased in RA $(2.45$ $(0.21)) v \mathrm{SpA}(0.55$ (0.25), $\mathrm{p}<0.001)$. The expression of both integrins on endothelium of sublining blood vessels was similar in both groups.

\section{Discussion}

Although the synovial membrane in RA has been analysed in numerous studies, little is known about the pathogenic relevance and specificity of the histological findings, such as synovial lining layer hyperplasia, neovascularisation, and inflammatory infiltration of the sublining with lymphocytes and macrophages. Either the use of surgical specimens created a possible bias with regard to disease duration and activity, or the studies failed to include an inflammatory, immune mediated joint disease as control. Our study was designed to exclude such biases by the use of needle arthroscopic biopsy specimens, and to describe subsequently disease-specific histological changes of the synovial membrane which might be of pathogenic or diagnostic relevance in RA and SpA.

A systematic comparison of early RA, defined as disease duration of less than one year, with established RA showed no major macroscopic or microscopic differences. The only exception, the increase of maximal lining layer thickness with disease duration, should be interpreted carefully as it might be explained by chance owing to multiple testing. These data are concordant with previous reports on inflammatory infiltration, $T$ cell activation, and expression of adhesion molecules and cytokines in early and late RA, ${ }^{10} 122830$ and support the concept that a number of histological and immunohistochemical findings are independent of disease duration. However, the present histological data do not allow us to conclude that the earliest phase of RA, which probably precedes the first clinical manifestations, and established disease are driven by similar immunological mechanisms. ${ }^{31}{ }^{32}$

To analyse the influence of local disease activity on synovial histology, patients with knee joint effusion and patients with knee pain only (without effusion) were studied. A first observation is that synovial tissue from knees without effusion can already depict some histological changes, such as inflammatory infiltration and increased vascularity, suggesting that the pain is not only due to secondary cartilage damage but also to synovial inflammation. This is not unexpected as histological changes were reported in clinically unaffected joints of patients with RA, ${ }^{833} 34$ suggesting an early pathogenic role for CD68+ macrophages and macrophage-derived proinflammatory cytokines in RA synovitis. Secondly, the inflammatory infiltration, as well as other histological variables, is strongly increased in patients with RA, SpA, and OA with joint effusion compared with patients without effusion. These data support the view that synovial his- tology is influenced by local disease activity, ${ }^{12}$ and question the use of non-inflammatory controls in comparative histology of the synovial membrane.

After stratification for local disease activity, systemic measures of disease activity, such as CRP and sedimentation rate, correlated only weakly with some histological features in RA but not in $\mathrm{SpA}$ and OA, which might be explained by the fact that they are not good measures of disease activity in SpA and OA. ${ }^{35}$

Beside disease duration and disease activity, drugs might also be a confounding factor in the histological study of synovial tissue as numerous previous studies have shown the effect of antirheumatic drugs on synovial histology. ${ }^{36-41}$ Although this issue was not analysed here and needs certainly to be considered in future studies, the fact that the use of non-steroidal anti-inflammatory drugs, disease modifying antirheumatic drugs, and corticosteroids was comparable in the different patient groups makes it unlikely that a possible drugs bias accounts for important differences in the comparison of RA, SpA, and OA.

When stratifying for local disease activity, no significant differences were found between patients with RA, SpA, and OA without joint effusion, which suggests that either these histological changes are not disease-specific, or that the semiquantitative approach used in this study is not sufficiently sensitive to detect small differences. In contrast, several significant disease related features were detected in the patients with RA and SpA with active joint effusion. Although it has to be considered that macroscopic scoring of the synovial membrane has not yet been validated, analysis of the synovial membrane during needle arthroscopy confirmed our previous report of an increased vascularity in SpA compared with RA. ${ }^{20}$ A recent report indicates that there is also a difference in morphology of the blood vessels between these two pathologies: tortuous vessels were seen in $73 \%$ of $\mathrm{SpA}$ and $11 \%$ of RA, whereas straight vessels were seen in $89 \%$ of RA and $26 \%$ of $\mathrm{SpA} .^{25}$ Our study confirms this observation, despite some minor discrepancies: (a) a straight vessel pattern is quite specific for but not very common in RA; (b) tortuous vessels are predominant in $\mathrm{SpA}$, but are also seen in RA; and (c) an important proportion of both groups has a mixed vascularity pattern. The increased vascularity in SpA compared with RA was confirmed at the microscopic level and is in agreement with previous studies in $\mathrm{PsA}^{42}$ and $\mathrm{SA}^{43}$ Taken together, the increased macroscopic and microscopic vascularity and the different morphology of the blood vessels indicate that neovascularisation might be mediated by different growth factors and/or receptors in RA and SpA, though the present study showed no difference in $\alpha \mathrm{V}$ integrin expression on endothelium. Furthermore, the present data indicate that neovascularisation might be even more important as a pathogenic mechanism and possible therapeutic target in $\mathrm{SpA}$ than in RA.

Conflicting results have been reported for the inflammatory infiltration of the synovium 
in RA compared with SpA. ${ }^{1028445}$ These discrepancies might be explained by the differences in SpA subtypes or the differences in microscopic evaluation, or both. This study indicates that manifest lymphocytic infiltration is present in both diseases, but that CD3+ cells, CD4+ cells, CD20+ cells, and lymphoid aggregates are clearly increased in RA. Interestingly, the score for CD8+ cells is not different. Although the study was not designed to compare the level of expression of two markers in the same tissue, this might reflect an increased $\mathrm{CD} 4 / \mathrm{CD} 8$ ratio in RA. Beside lymphocytes, no differences are seen in other cell types infiltrating the sublining layer, but although the relatively small number of patients in each $\mathrm{SpA}$ subgroup allows only preliminary observations, a slight but significant increase of neutrophils was noted in PsA compared with other $\mathrm{SpA}$ subtypes and RA (data not shown).

Finally, the expression of the integrins $\alpha \mathrm{V} \beta 3$ and $\alpha \mathrm{V} \beta 5$ was compared between RA and $\mathrm{SpA}$. These integrins can be expressed on endothelial cells, where they mediate angiogenesis, ${ }^{46} 47$ and on synovial fibroblasts. ${ }^{12}{ }^{48}$ In this study both integrins are expressed to a similar degree on endothelium in RA and SpA, indicating an important synovial neovascularisation in both diseases. On synovial fibroblasts, however, RA is characterised by a strongly significant decrease of $\alpha \mathrm{V} \beta 3$ in the synovial lining layer and increase of $\alpha \mathrm{V} \beta 5$ in the sublining layer. As engagement of $\alpha \mathrm{V}$ integrins regulates proliferation, migration, and collagenase expression of a variety of cell types, ${ }^{48-52}$ this differential integrin expression may have an important role in the aggressive growth of the synovial pannus in RA.

In conclusion, synovial histology is dependent on local disease activity but not on disease duration in clinically manifest RA. Comparative histology after stratification for this confounding factor allows the description of disease related changes of the synovial membrane, including neovascularisation in $\mathrm{SpA}, \mathrm{T}$ and $\mathrm{B}$ cell infiltration in RA, and differential $\alpha \mathrm{V}$ integrin expression. The presence of a disease related immune architecture of the synovial membrane warrants further investigation of the pathophysiological and/or diagnostic relevance of these findings.

Dominique Baeten is an FWO-Vlaanderen research assistant. This work was supported by an NFWO-grant 3.0022.96 and concerted action grant GOA96001 of the University of Ghent, Belgium. We thank Miss J Vermeersch for outstanding technical contribution to this study.

1 Mulherin D, Fitzgerald O, Bresnihan B. Synovial tissue macrophage populations and articular damage in rheumatoid arthritis. Arthritis Rheum 1996;39:115-24.

2 Lalor PA, Mapp PI, Hall PA, Revell PA. Proliferative activity of cells in the synovium as demonstrated by a monoclonal antibody, Ki67. Rheumatol Int 1987;7:183-6.

3 Qu Z, Garcia CH, O'Rourke LM, Planck SR, Kohli M, Rosenbaum JT. Local proliferation of fibroblast-like synoviocytes contributes to synovial hyperplasia: results of proliferating cell nuclear antigen/cyclin, c-myc, and nucleolar organizer region staining. Arthritis Rheum 1994;37: 212-20.

4 Firestein GS, Yeo M, Zvaifler NJ. Apoptosis in rheumatoid arthritis synovium. J Clin Invest 1995;96:1631-8.

5 Firestein GS, Echeverri F, Yeo M, Zvaifler NJ, Green DR. Firestein GS, Echeverri F, Yeo M, Zvaifler NJ, Green DR.
Somatic mutations in the p53 tumor suppressor gene in Somatic mutations in the p53 tumor suppressor gene in
rheumatoid arthritis synovium. Proc Natl Acad Sci USA 1997;94:10895-900.
6 Paleolog EM. Angiogenesis: a critical process in the pathogenesis of RA- role for VEGF? Br J Rheumatol 1996;35: 917-20.

7 Ceponis A, Konttinen YT, Mackevicius Z, Solovieva SA, Hukkanen $M$, Tamulaitiene $M$, et al. Aberrant vascularity and von Willebrand factor distribution in inflamed synovial membrane. J Rheumatol 1996;23:1880-6.

8 FitzGerald O, Soden M, Yanni G, Robinson R, Bresnihan B. Morphometric analysis of blood vessels in synovial membranes obtained from clinically affected and unaffected knee joints of patients with rheumatoid arthritis. Ann Rheum Dis 1991;50:792-6.

9 Potocnik AJ, Kinne E, Menninger H, Zacher J, Emmrich F, Kroczek RA. Expression of activation antigens on T cells in Kroczek RA. Expression of activation antigens on T cells in
rheumatoid arthritis patients. Scand J Immunol 1990;31: 213-24.

10 Smeets TJM, Dolhain RJEM, Breedveld FC, Tap PP. Analysis of the cellular infiltrates and expression of cytokines in synovial tissue from patients with rheumatoid arthritis and reactive arthritis. J Pathol 1998;186:75-81.

11 Tak PP, Hintzen RQ, Teunissen JJM, Smeets TJM, Daha MR, Van Lier RAW, et al. Expression of the activation antigen CD27 in rheumatoid arthritis. Clin Immunol Immunopathol 1996;80:129-38.

12 Tak PP, Smeets TJM, Daha MR, Kluin PM, Meijers KAE, Brand R. Analysis of the synovial cell infiltrate in early rheumatoid synovial tissue in relation to local disease activrheumatoid synovial tissue in relation

13 Johnson BA, Haines GK, Harlow LA, Koch AE. Adhesion molecule expression in human synovial tissue. Arthritis Rheum 1993;36:137-46.

14 Nikkari L, Haapasalmi K, Aho H, Torvinen A, Sheppard D, Larjava $\mathrm{H}$, et al. Localization of the $\alpha \mathrm{V}$ subfamily of integrins and their putative ligands in the synovial lining cell layer. J Rheumatol 1995;22:16-23.

15 Zvaifler NJ. Rheumatoid arthritis-the multiple pathways to chronic synovitis. Lab Invest 1995;73:307-10.

16 Firestein GS, Zvaifler NJ. How important are T cells in chronic rheumatoid synovitis? Arthritis Rheum 1990;33: 768-73.

17 Zvaifler NJ, Firestein GS. Pannus and pannocytes: alternative models of joint destruction in rheumatoid arthritis. Arthritis Rheum 1994;37:783-9.

18 Lindblad S, Hedfors E. Intraarticular variation in synovitis. Local macroscopic and microscopic signs of inflammatory activity are significantly correlated. Arthritis Rheum 1985; 28:977-86.

19 Haraoui B, Pelletier JP, Cloutier JM, Faure MP, MartelPelletier J. Synovial membrane histology and immunopathology in rheumatoid arthritis and osteoarthritis. Arthritis Rheum 1991;34:153-63.

20 Baeten D, Van Den Bosch F, Elewaut D, Stuer A, Veys EM, De Keyser F. Needle arthroscopy of the knee with synovial biopsy sampling: technical experience in 150 patients. Clin biopsy sampling: technical exper

21 Arnett FC, Edworthy SM, Bloch DA, McShane DJ, Fries JF, Cooper NS, et al. The American Rheumatism Association 1987 revised criteria for the classification of rheumatoid arthritis. Arthritis Rheum 1988;31:315-24.

22 Dougados $M$, van der Linden S, Juhlin R, Huitfeldt B, Amor B, Calin A, et al. The European Spondyloarthropathy Study Group preliminary criteria for the classification of spondyloarthropathy. Arthritis Rheum 1991;34:121827.

23 Altman R, Asch E, Bloch D, Bole G, Borenstein D, Brandt $\mathrm{K}$, et al. Development of criteria for the classification and reporting of osteoarthritis: classification of osteoarthritis of reporting of osteoarthritis: classification of os

24 Steinbrocker O, Trager GH, Butterman RC. Therapeutic criteria in rheumatoid arthritis. JAMA 1949;140:659-62.

25 Reece RJ, Canete JD, Parsons WJ, Emery P, Veale DJ. Distinct vascular patterns of early synovitis in psoriatic, reactive, and rheumatoid arthritis. Arthritis Rheum 1999; 42:1481-4.

26 Tak PP, Kummer JA, Hack CE, Daha MR, Smeets TJM, Erkelens GW, et al. Granzyme positive cytotoxic cells are specifically increased in early rheumatoid synovial tissue. Arthritis Rheum 1994;37:1735-43.

27 Dolhain RJEM, Ter Haar NT, Hoefakker S, Tak PP, De Ley $\mathrm{M}$, Claassen $\mathrm{E}$, et al. Increased expression of interferon (IFN)-gamma together with IFN-gamma receptor in the rheumatoid synovial membrane compared with synovium rheumatoid synovial membrane compared with synovium of patie.

28 Tak PP, Thurkow EW, Daha MR, Kluin PM, Smeets YJM, Meinders AE, et al. Expression of adhesion molecules in early rheumatoid synovial tissue. Clin Immunol Immunopathol 1995;77:236-42.

29 Bresnihan B, Cunnane G, Youssef P, Yanni G, FitzGerald O, Mulherin D. Microscopic measurement of synovial membrane inflammation in rheumatoid arthritis: proposals for the evaluation of tissue samples by quantitative analysis. $\mathrm{Br}$ J Rheumatol 1998;37:636-42.

30 Smeets TJM, Dolhain RJEM, Miltenburg AMM, de Kuiper $\mathrm{R}$, Breedveld FC, Tak PP. Poor expression of T cell derived cytokines and activation and proliferation markers in early rheumatoid synovial tissue. Clin Immunol Immunopathol 1998;88:84-90.

31 Bucht A, Oksenberg JR, Lindblad S, Gronberg A, Steinman L, Klareskog L. Characterization of T cell receptor alpha beta repertoire in synovial tissue from different temporal beta repertoire in synovial tissue from different temporal
phases of rheumatoid arthritis. Scand J Immunol 1992;35: 159-65. 
32 Elewaut D, De Keyser F, Van den Bosch F, Verbruggen G, Veys EM. Broadening of the $T$ cell receptor spectrum disease duration. Clin Exp Rheumatol 2000;18:201-7.

33 Soden M, Rooney M, Cullen A, Whelan A, Feighery C, Bresnihan B. Immunohistological features in the synovium obtained from clinically uninvolved knee joints of patients with rheumatoid arthritis. Br J Rheumatol 1989;28:28792.

34 Kraan MC, Versendaal H, Jonker M, Bresnihan B, Post WJ, 'T Hart BA, et al. Asymptomatic synovitis precedes clinically

35 Spoorenberg A, van der Heijde D, de Klerk E, Dougados M, de Vlam $\mathrm{K}$, Mielants $\mathrm{H}$, et al. Erythrocyte sedimentation rate (ESR) versus $C$-reactive protein (CRP) in ankylosing spondylitis (AS) [abstract]. Arthritis Rheum 1998;41: S287.

36 Tak PP, Van Der Lubbe PA, Cauli A, Daha MR, Smeets TJM, Kluin PM, et al. Reduction of synovial inflammation after anti-CD4 monoclonal antibody treatment in early

37 Veale DJ, Reece RJ, Parsons W, Radjenovic A, O'Connor PJ, Orgles CS, et al. Intra-articular primatised anti-CD4 efficacy in resistant rheumatoid knees. A study of combined arthroscopy, magnetic resonance imaging, and histology. Ann Rheum Dis 1999;58:342-9.

38 Youssef PP, Haynes DR, Triantafillou S, Parker A, Gamble JR, Roberts-Thomson PJ, et al. Effects of pulse methylprednisolone on inflammatory mediators in peripheral blood, synovial fluid, and synovial membrane in rheumatoid arthritis. Arthritis Rheum 1997;40:1400-8.

39 Smeets TJM, Dayer JM, Kraan MC, Versendaal J, Chicheportiche R, Breedveld FC, et al. The effect of interferon- $\beta$ treatment on synovial inflammation and expression of metalloproteinases in patients with rheumatoid arthritis. Arthritis Rheum 2000;43:259-69.

40 Tak PP, Taylor PC, Breedveld FC, Smeets TJM, Daha ME, Kluin PM, et al. Decrease in cellularity and expression of adhesion molecules by anti-tumor necrosis factor $\alpha$ monoclonal antibody treatment in patients with

41 Taylor PC, Peters AM, Paleolog E, Chapman PT, Elliot MJ, McCloskey R, et al. Reduction of chemokine levels and leucocyte traffic to joints by tumor necrosis factor $\alpha$ blockade in patients with rheumatoid arthritis. Arthritis Rheum 2000;43:38-47.
42 Veale D, Yanni G, Rogers S, Barnes L, Bresnihan B, FitzGerald O. Reduced synovial membrane macrophage numbers, ELAM-1 expression, and lining layer hyperplasia in psoriatic arthritis as compared with rheumatoid arthritis. Arthritis Rheum 1993;36:893-900.

43 Cunnane G, Bresnihan B, FitzGerald O. Immunohistologic analysis of peripheral joint disease in ankylosing spondylitis. Arthritis Rheum 1998;41:180-2

44 Smith MD, O'Donnell J, Highton J, Palmer DG, Rozenbilds $M$, Roberts-Thomson PJ. Immunohistochemical analysis of synovial membranes from inflammatory and noninflammatory arthritides: scarcity of CD 5 positive B cells and IL2 receptor bearing T cells. Pathology 1992;24:1926.

45 Kidd BL, Moore K, Walters MT, Smith JL, Cawley MID. Immunohistological features of synovitis in ankylosing spondylitis: a comparison with rheumatoid arthritis. Ann Rheum Dis 1989;48:92-8.

46 Koch AE. Angiogenesis. Implications for rheumatoid arthritis. Arthritis Rheum 1998;41:951-62.

47 Johnson BA, Haines GK, Harlow LA, Koch AE. Adhesion molecule expression in human synovial tissue. Arthritis Rheum 1993;36:137-46.

48 Sarkissian M, Lafyatis R. Integrin engagement regulates proliferation and collagenase expression of rheumatoid synovial fibroblasts. J Immunol 1999;162:1772-9.

49 Srivasta SS, Fitzpatrick LA, Tsao PW, Reilly TM, Holmes $\mathrm{DR}$, Schwartz RS, et al. Selective $\alpha \mathrm{V} \beta 3$ integrin blockade potently limits neointimal hyperplasia and lumen stenosis following deep coronary arterial stent injury: evidence for the functional importance of integrin $\alpha \mathrm{V} \beta 3$ and osteopontin expression during neointima formation. Cardiovasc Res 1997;36:408-28.

50 Horton MA, Taylor L, Arnett TR, Helfrich MH. Arg-GlyAsp (RGD) peptides and the anti-vitronectin receptor antibody 23C6 inhibit dentine resorption and cell spreading by osteoclasts. Exp Cell Res 1991;195:368-75.

51 Seftor REB, Seftor EA, Gehlsen KR, Stetler-Stevenson WG, Brown PD, Ruoslathi E, et al. Role of the $\alpha \mathrm{V} \beta 3$ integrin in human melanoma cell invasion. Proc Natl Acad Sci USA 1992;89:1557-61.

52 Stefansson S, Lawrence DA. The serpin PAI-1 inhibits cell migration by blocking integrin $\alpha \mathrm{V} \beta 3$ binding to vitronectin. Nature 1996;383:441-3 